\author{
A. Nagy, Miskolc, Hungary
}

\title{
INFLUENCE OF MEASUREMENT SETTINGS ON AREAL ROUGHNESS WITH CONFOCAL CHROMATIC SENSOR ON FACE-MILLED SURFACE
}

\begin{abstract}
Roughness measurement is of highlighted importance in production for describing the quality control of manufacturing processes for the functional, tribological, etc. properties of the surfaces of parts. In the last 15 years or so the areal roughness studied on topographies has also become more common, as it provides a more accurate and detailed characterization of the surfaces. However, with relatively little experience and different technical conditions, topographies are analyzed differently. Sometimes $3 D$ topography is used only as an illustration; however, spatial roughness measurement can provide much more information. The effect of measurement speed and point density during roughness measurement on the areal roughness was investigated using a confocal chromatic sensor.
\end{abstract}

Keywords: surface roughness; areal roughness; confocal chromatic sensor.

\section{INTRODUCTION}

Surface roughness is the most commonly used indicator to describe surface quality [1]; therefore, roughness measurement has an emphasized importance in production, which, serves as a tool to describe operational, tribological, and other properties in addition to maintaining quality control of production processes. In the products, the connecting surfaces must perform predictably, due to the functional or application properties prescribed for the components. This is important, for example, regarding sliding friction phenomena and thus wear. A clear definition of the relationships between the technological and application properties of surfaces is complicated, so it is difficult to infer the functional properties of surfaces directly from the profile and spatial roughness parameters of the surfaces [1].

The study of the measurement conditions is also justified by the fact that more and more complex surfaces can be produced, and the increase of productivity and the kinematic solutions applied on machine tools and the technological settings also require more accurate analysis. For example, greater feed rates [2] increase productivity but significantly affect roughness, which increases the difference between roughness values measured in different directions in face milling $[3,4]$.

The roughness of a surface along a profile has been studied for more than 100 years [5], and various methods have been developed to perform the measurements. Based on many years of experience, agreements have been established to unify recording settings in measurement operations, which have been incorporated into various national and international standards.

In the last decade and a half, the areal roughness studied on topographies has also become more widespread, as it provides a more accurate and detailed characterization

(C) A. Nagy, 2020 
of the surfaces than profile examination. However, information obtained from topographies is still not handled in a professional manner [6]. In the following, the overview shows the parameters along which the surfaces can be examined on the measuring device(s).

Klauer et al. [7] examined topographies produced by micro milling on a brass alloy where the tilt angle of the tool axis was changed. The surfaces were analyzed at several locations with a confocal microscope and Gaussian filter was used to evaluate the roughness measurements. Furthermore, based on the distance of a period on the machined topography, two standard L-filters $\left(\lambda_{c}=80\right.$ and $\left.25 \mu \mathrm{m}\right)$ were set and an S-filter $\left(\lambda_{\mathrm{s}}=5 \mu \mathrm{m}\right)$ was used for the latter to remove the noise of the measurement signal. With the two settings, they examined which filter values have a better correlation with the roughness of the surfaces. The values of $S_{a}$ and $S_{q}$ were examined.

Topographies of mono- and polycrystalline ceramics machined by grinding and lapping were studied by Niemczewska-Wójcik et al. [8]. The surfaces were measured with a white light interferometry microscope. Height, spatial, and functional parameters of areal roughness were examined along with $R_{a}$ average roughness. For the roughness test, an S-filter was used to eliminate the measurement noise and a threshold to eliminate irrelevant valleys and peaks.

In high-speed face milling of magnesium alloy with a PCD tool, the effect of machining parameters $\left(v_{c}, f_{z}, a_{p}\right)$ on the surface roughness was investigated [1]. The surfaces were measured with a stylus gauge, the main direction of which was adjusted perpendicular to the edge traces. In the evaluation a Gaussian filter was used, but no information was reported on other steps. In the article, height roughness indices were investigated, and the Abbott-Firestone curve was also analyzed in relation to $S_{\mathrm{sk}}$ and $S_{\mathrm{ku}}$ parameters.

Wojciechowski et al. [9] studied the effect of change of cutting speed while grooving with a diamond dispersed cemented carbide tool. Here the topography of the surface was not influenced by the feed rate, but mainly by the microprofile of the cutting edge, the vibrations of the machining system and the decohesive mechanisms of the material. The roughness of the machined surfaces was measured with both stylus and optical devices. The profiles were examined with L-filter $(2.5 \mathrm{~mm})$ and Gaussian filter, though the method of evaluation of the topography was not reported. Height areal roughness indices were examined in correlation with the cutting speed.

To achieve the required surface quality in Wire EDM, Mouralova et al. analyzed the effect of cutting speed and determined the optimal value [10]. Topographies were measured with a contactless $3 \mathrm{D}$ profilometer. The primary and roughness profile parameters and the areal roughness $S_{\mathrm{a}}, \mathrm{S}_{\mathrm{z}}$ and $\mathrm{S}_{\mathrm{q}}$ of the $\mathrm{S}-\mathrm{F}$ surfaces were analyzed. Methods of measurement and evaluation were not reported.

Most of the publications dealing with the determination of surface roughness parameter values do not justify the choice of the values set on the roughness measuring instrument. Furthermore, the literature review also shows that topographies are 
examined in different ways in terms of size of measured areas, measurement settings and evaluations, so it is not possible to accurately compare machined surfaces.

\section{EXPERIMENTAL METHOD AND CONDITIONS}

In this paper, the aim of the study is to analyze the effects of the roughness measurement setting options on the values of the areal roughness parameters with the confocal chromatic sensor of the roughness measuring device. In doing so, I vary the measurement speed and the distance between the measured points to examine how and to what extent they affect the roughness values.

\subsection{EXPERIMENTAL METHOD}

Information on the measurement of areal roughness of the topography is given in the international standard ISO 25178:2012. A part of this, ISO 25178-3:2012 [11] gives a recommendation for measurements, which are briefly the following. The tested topography should be square, the main test direction should be the same as described in the relevant standard for profile measurement. The shape deviation on the measured surface should be removed according to the nominal shape, and the S-filter separating the micro-roughness and the cut-off length of the L-filter separating the roughness from the waviness should be used as Gaussian filtering in both $\mathrm{X}$ and $\mathrm{Y}$ directions. The value of the L-filter can be selected from the attached table in [11], which may be the same as the corresponding value in ISO 4288:1998. The measuring length should be five times the length of the L-filter in the main direction. I conducted my studies in compliance with these.

The following parameters can be set during roughness measurement:

- Distance between the points in the main measuring direction (X direction)

- Measuring speed in the main measuring direction

- Distance between the points in the perpendicular measuring direction (Y direction)

- Measured area size; start, center and end point

- Type of sensor used for the measurement and the associated configuration data

- Brightness of the emitted light beam.

However, not all of these parameters affect the accuracy of the measurement. The brightness of the light beam has no effect if the sensor can read all the points examined on the surface. Therefore, I set it based on a scan on the entire surface in advance; there was not too little or too much reflected light to the detector. Then I pre-selected the type of sensor used for the measurements; in this respect it does not affect the result. Furthermore, the size of the measured area may determine the accuracy of the roughness, but I selected it in advance based on the above recommendations, and I also defined the measurement positions, so I will not examine their effect now. So, I 
determined the measurement setting parameters - the density of the point and the measurement speed - by changing factors that can influence the accuracy.

First, I examine the effect of measurement speed. The measuring program limits this in the main direction by the product of the point distance in the discussed direction and the sampling frequency. On the other hand, if the height value of the points is read equally as often or less frequently than the set frequency of an optical sensor, this theoretically has no effect on the accuracy of the measurement. To prove this, I measured area B (see Figure 1) at different velocities and examine the effect of the speed on roughness. The point distances in X, Y directions were the same. Next, I analyze the effect of the density of the Y-direction points on the roughness in the three measurement areas (see Figure 1). Here, I did not change the other two setting data: the $\mathrm{X}$-direction velocity and the main-direction point density. Finally, I examine the effect of X-direction point density, where I kept the X-direction velocity and the Y-direction point distance constant. The set data is summarized in Table 1 . In each case, I compare the values of some frequently used areal roughness parameters defined by ISO 25178-2:2012.

Table 1 - Values set during measurement

\begin{tabular}{|l|l|ll|}
\hline Examined parameter & Fixed values & \\
\hline $\begin{array}{l}\text { Velocity in } \\
\text { direction } X\end{array}$ & $\begin{array}{l}\mathrm{v}_{\mathrm{x}}=200,300,400,500,600, \\
700,800,900,1000 \mu \mathrm{m} / \mathrm{s}\end{array}$ & $\mathrm{X}=1 \mu \mathrm{m}$, & $\mathrm{Y}=20 \mu \mathrm{m}$ \\
\hline Point distance in $\mathrm{Y}$ & $\mathrm{Y}=1,2,5,10,15,20,25 \mu \mathrm{m}$ & $\mathrm{v}_{\mathrm{x}}=1000 \mu \mathrm{m} / \mathrm{s}$, & $\mathrm{X}=1 \mu \mathrm{m}$ \\
\hline Point distance in $\mathrm{X}$ & $\mathrm{X}=1,2,3,4,5,6,7 \mu \mathrm{m}$ & $\mathrm{v}_{\mathrm{x}}=1000 \mu \mathrm{m} / \mathrm{s}$, & $\mathrm{Y}=10 \mu \mathrm{m}$ \\
\hline
\end{tabular}

\subsection{EXPERIMENTAL CONDITIONS}

For the topography examination, a specimen was machined on a Perfect Jet MCV-M8 vertical CNC milling machine. A Sandvik R252.44-080027-15M face milling head with a Sandvik R215.44-15T308M-WL type, GC4030 grade coated carbide insert in only one nest was used, with the geometry $\kappa_{\mathrm{r}}=90^{\circ}, \kappa_{\mathrm{r}}{ }^{\prime}=1.5^{\circ} \gamma_{0}=0^{\circ} ; \alpha_{0}=11^{\circ} ; \mathrm{r}_{\varepsilon}=0.8 \mathrm{~mm}$. The workpiece was made of normalized C45 non-alloy steel (1.0503) with a machined surface of $50 \times 58 \mathrm{~mm}^{2}$. The cutting data were as follows: cutting speed $\mathrm{v}_{\mathrm{c}}=300 \mathrm{~m} / \mathrm{min}$, depth of cut $\mathrm{a}_{\mathrm{p}}=0.8 \mathrm{~mm}$, width of cut $\mathrm{a}_{\mathrm{e}}=58 \mathrm{~mm}$, feed rate per tooth $\mathrm{f}_{\mathrm{z}}=0.1 \mathrm{~mm} / \mathrm{rev}$. Due to the tool axis position perpendicular to the working plane, double cutting marks formed on the surface.

An AltiSurf 520 three-dimensional roughness measuring instrument was used for the measurements on the specimen. I measured the surface with a CL2 confocal chromatic sensor with a MG140 magnifier, which has the vertical measurement range $300 \mu \mathrm{m}$ and its sensitivity $0.012 \mu \mathrm{m}$. The sampling frequency of the gauge is $1000 \mathrm{~Hz}$. The position of the measured areas is illustrated in Figure 1, their size was chosen to $1.25 \times 1.25 \mathrm{~mm}^{2}$, based on the recommendation of ISO 25178-3:2012 [11]. 
I repeated each measurement setting three times, and their arithmetic mean values were used for the examinations.
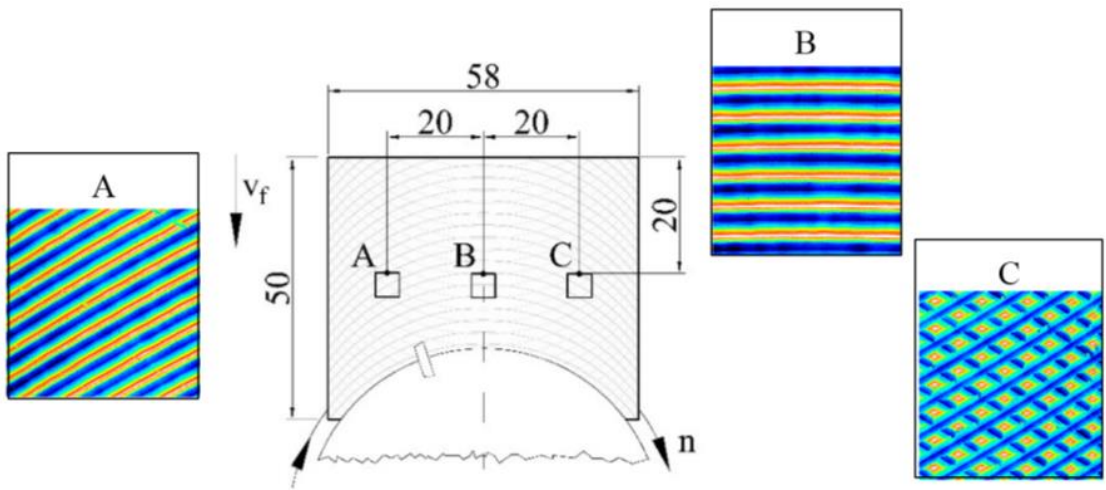

Figure 1 - Positions of the measured areas

There are different tools for measuring surface topography with variable measuring range and vertical accuracy, e.g. coordinate measuring machine, stylus profilometer, interference microscope, confocal microscope, SEM, AFM, STM, etc. Although contact measurement techniques can map topographies with high resolution over a wide measurement range, they are relatively slow and can damage samples. Contactless procedures are used to avoid this. Optical instruments became popular when it was realized that the information obtained from profile measurements was not sufficient for the functional properties of machined parts, but could be satisfied by topographic measurements, and optical instruments could quickly evaluate the surface texture of the area [6]. The measuring range of the confocal chromatic sensor I used is relatively small; however, its vertical resolution is below $\mu \mathrm{m}$, which is suitable for the examination of surfaces machined with defined edge tools.

The evaluation of the measurements was executed in AltiMap Premium v6.2 software. In each case, I applied different filters on the S-L surfaces, first eliminating the shape defect, which means leveling on a flat surface. Then, with the Threshold function, I cut off the faulty parts on the topographies, and finally I set a Gaussian filter and with it an L-filter $\left(\lambda_{c}=0.25 \mathrm{~mm}\right)$ too.

\section{RESULTS AND DISCUSSION}

First, I analyze the effect of X-direction measurement velocity on roughness. For this, I summarize the results in Table 2 and plot them in Figure 3, in which I bound the range of deviation of each parameter value and indicate its value. 
Table 2 - Roughness values according to X-direction measurement speed

\begin{tabular}{|l|l|l|l|l|l|l|l|l|l|}
\hline $\begin{array}{l}\text { Speed } \\
{[\mu \mathrm{m} / \mathrm{s}]}\end{array}$ & $\mathbf{2 0 0}$ & $\mathbf{3 0 0}$ & $\mathbf{4 0 0}$ & $\mathbf{5 0 0}$ & $\mathbf{6 0 0}$ & $\mathbf{7 0 0}$ & $\mathbf{8 0 0}$ & $\mathbf{9 0 0}$ & $\mathbf{1 0 0 0}$ \\
\hline $\mathrm{S}_{\mathrm{q}}[\mu \mathrm{m}]$ & 0.490 & 0.488 & 0.486 & 0.488 & 0.486 & 0.485 & 0.485 & 0.484 & 0.485 \\
\hline $\mathrm{S}_{\mathrm{a}}[\mu \mathrm{m}]$ & 0.419 & 0.417 & 0.415 & 0.416 & 0.414 & 0.415 & 0.413 & 0.413 & 0.415 \\
\hline $\mathrm{S}_{\mathrm{z}}[\mu \mathrm{m}]$ & 2.761 & 2.743 & 2.702 & 2.752 & 2.658 & 2.669 & 2.679 & 2.653 & 2.640 \\
\hline $\mathrm{S}_{\mathrm{sk}}[-]$ & 0.481 & 0.479 & 0.482 & 0.481 & 0.479 & 0.461 & 0.468 & 0.466 & 0.466 \\
\hline $\mathrm{S}_{\text {ku }}[-]$ & 2.129 & 2.136 & 2.140 & 2.131 & 2.121 & 2.113 & 2.123 & 2.111 & 2.095 \\
\hline
\end{tabular}

The values of each parameter change slightly, each has a deviation within $0.5-4.5 \%$. Among the parameters $S_{z}$ total height shows maximum fluctuation. Furthermore, regarding $S_{q}$ and $S_{a}$, the values do not show monotony, they occupy random places in their deviation zone. However, the values of $S_{\mathrm{z}}, S_{\mathrm{sk}}$, and $S_{\mathrm{ku}}$ appear to decrease at higher velocities for the most part in the studied range. Considering the values of the parameters together, it can be stated that any value can be used in the speed range between 700 and $1000 \mu \mathrm{m} / \mathrm{s}$ can be used, in which case only minimal error should be expected.

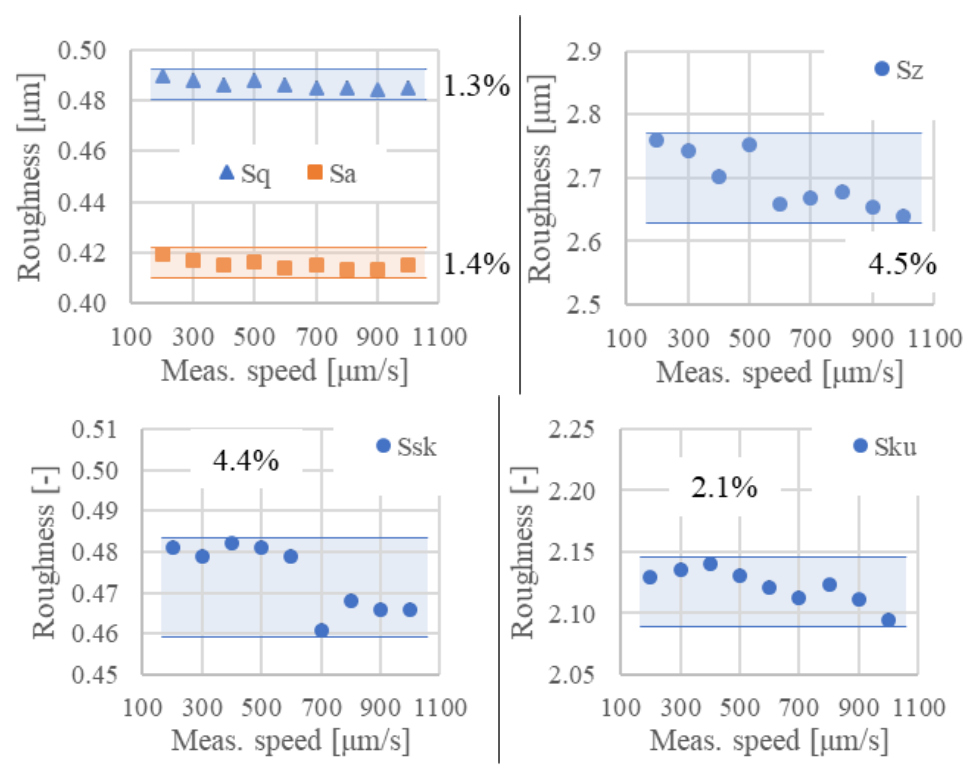

Figure 2 - Roughness values as a function of measurement speed 
Table 3 - Roughness values according to Y-direction point density

\begin{tabular}{|c|c|c|c|c|c|c|c|c|}
\hline $\begin{array}{l}\text { Distance } \\
{[\mu \mathrm{m}]}\end{array}$ & Area & 1 & 2 & 5 & 10 & 15 & 20 & 25 \\
\hline \multirow{3}{*}{$\mathrm{S}_{\mathrm{q}}[\mu \mathrm{m}]$} & A & 0.493 & 0.481 & 0.471 & 0.464 & 0.465 & 0.419 & 0.422 \\
\hline & B & 0.483 & 0.484 & 0.483 & 0.475 & 0.477 & 0.487 & 0.477 \\
\hline & $\mathrm{C}$ & 0.518 & 0.516 & 0.498 & 0.469 & 0.475 & 0.422 & 0.430 \\
\hline \multirow{3}{*}{$\mathrm{S}_{\mathrm{a}}[\mu \mathrm{m}]$} & $\mathrm{A}$ & 0.413 & 0.403 & 0.394 & 0.393 & 0.394 & 0.360 & 0.356 \\
\hline & B & 0.415 & 0.416 & 0.415 & 0.409 & 0.410 & 0.417 & 0.410 \\
\hline & $\mathrm{C}$ & 0.422 & 0.421 & 0.407 & 0.390 & 0.390 & 0.352 & 0.353 \\
\hline \multirow{3}{*}{$\mathrm{S}_{\mathrm{z}}[\mu \mathrm{m}]$} & A & 2.764 & 2.671 & 2.546 & 2.376 & 2.450 & 2.289 & 2.393 \\
\hline & B & 2.782 & 2.770 & 2.562 & 2.431 & 2.481 & 2.646 & 2.326 \\
\hline & $\mathrm{C}$ & 2.717 & 2.712 & 2.524 & 2.434 & 2.524 & 2.318 & 2.398 \\
\hline \multirow{3}{*}{$\mathrm{S}_{\mathrm{sk}}[-]$} & A & 0.563 & 0.552 & 0.546 & 0.500 & 0.506 & 0.402 & 0.450 \\
\hline & B & 0.458 & 0.448 & 0.443 & 0.427 & 0.433 & 0.465 & 0.415 \\
\hline & $\mathrm{C}$ & 0.632 & 0.622 & 0.603 & 0.536 & 0.555 & 0.453 & 0.546 \\
\hline \multirow{3}{*}{$S_{\mathrm{ku}}[-]$} & $\mathrm{A}$ & 2.223 & 2.184 & 2.157 & 2.079 & 2.126 & 2.018 & 2.208 \\
\hline & B & 2.041 & 2.016 & 1.988 & 1.946 & 1.971 & 2.096 & 1.946 \\
\hline & $\mathrm{C}$ & 2.474 & 2.434 & 2.369 & 2.229 & 2.318 & 2.218 & 2.447 \\
\hline
\end{tabular}

Next, I analyze the effect of the Y-direction point spacing on the roughness in the three measurement areas (see Figure 1), for which I give the results of the roughness parameters in Table 3 and plot them in diagrams (Figure 3).

On the specimen surface, the value pairs of the side areas are always similar, but the value of area B differs to a greater extent in some cases. However, here the smallest derivation of the values is observed. The nature of the change in the values of each area as a function of distance is random, it cannot be determined exactly. By observing the development of the roughness values together in all three planes, I find that by setting the distance between 5 and $15 \mu \mathrm{m}$, roughness results can be obtained with the smallest error.

The effect of the setting of X-direction point density is shown in the following. For this, the roughness values in the three measurement areas are gathered in Table 4 and plotted in Figure 4. The changes in the values measured on the surface in all three areas are of the same nature and magnitude as a function of distance. One case is an exception; for the index $S_{z}$ in area $B$, the values decrease more significantly as the distance increases. The values of the parameters $S_{\mathrm{sk}}$ and $S_{\mathrm{ku}}$ change very little, so by setting any spacing value within the examined range, we obtain almost the same roughness parameters, with minimal error. Regarding the values of $S_{\mathrm{q}}, S_{\mathrm{a}}$ and $\mathrm{S}_{\mathrm{z}}$, it was found that for the 
setting parameter in the range of 1 and $3 \mu \mathrm{m}$ there is a little difference between the values, so any value in the range can be used with minimal error.
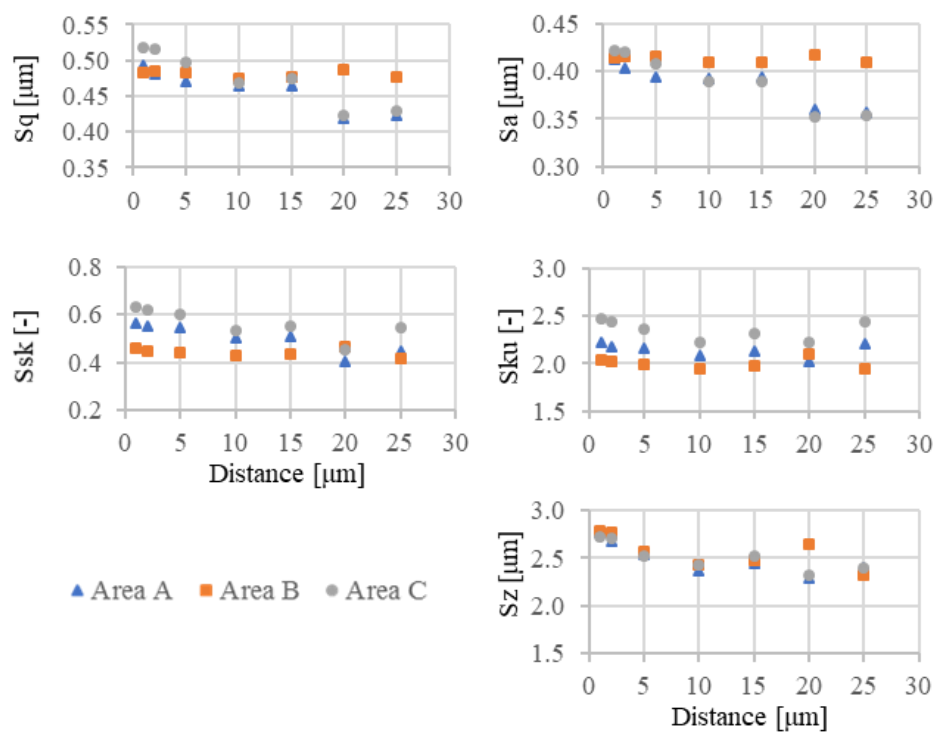

Figure 3 - Roughness values as a function of Y-direction point density

Table 4 - Roughness values according to X-direction point density

\begin{tabular}{|l|l|l|l|l|l|l|l|l|}
\hline Distance $[\mu \mathrm{m}]$ & Area & $\mathbf{1}$ & $\mathbf{2}$ & $\mathbf{3}$ & $\mathbf{4}$ & $\mathbf{5}$ & $\mathbf{6}$ & $\mathbf{7}$ \\
\hline \multirow{3}{*}{$\mathrm{S}_{\mathrm{q}}[\mu \mathrm{m}]$} & A & 0.464 & 0.458 & 0.457 & 0.445 & 0.443 & 0.442 & 0.438 \\
\cline { 2 - 10 } & B & 0.475 & 0.469 & 0.469 & 0.461 & 0.456 & 0.448 & 0.447 \\
\cline { 2 - 9 } & C & 0.469 & 0.462 & 0.460 & 0.449 & 0.447 & 0.438 & 0.434 \\
\hline \multirow{3}{*}{$S_{\text {a }}[\mu \mathrm{m}]$} & A & 0.393 & 0.388 & 0.386 & 0.377 & 0.375 & 0.375 & 0.373 \\
\cline { 2 - 9 } & B & 0.409 & 0.405 & 0.405 & 0.402 & 0.395 & 0.391 & 0.391 \\
\cline { 2 - 9 } & C & 0.390 & 0.384 & 0.383 & 0.375 & 0.375 & 0.367 & 0.363 \\
\hline \multirow{3}{*}{$S_{\text {z }}[\mu \mathrm{m}]$} & A & 2.376 & 2.346 & 2.363 & 2.276 & 2.275 & 2.242 & 2.168 \\
\cline { 2 - 9 } & B & 2.431 & 2.404 & 2.378 & 2.149 & 2.159 & 2.016 & 1.971 \\
\cline { 2 - 9 } & C & 2.434 & 2.422 & 2.394 & 2.368 & 2.363 & 2.170 & 2.132 \\
\hline \multirow{3}{*}{$S_{\text {sk }}[-]$} & A & 0.500 & 0.498 & 0.494 & 0.473 & 0.459 & 0.460 & 0.450 \\
\cline { 2 - 9 } & B & 0.427 & 0.418 & 0.418 & 0.403 & 0.380 & 0.361 & 0.354 \\
\cline { 2 - 9 } & C & 0.536 & 0.533 & 0.530 & 0.511 & 0.506 & 0.492 & 0.484 \\
\hline$S_{\text {ku }}[-]$ & A & 2.079 & 2.065 & 2.063 & 2.024 & 2.010 & 1.992 & 1.978 \\
\hline
\end{tabular}




\begin{tabular}{|l|l|l|l|l|l|l|l|l|}
\hline & B & 1.946 & 1.908 & 1.904 & 1.845 & 1.880 & 1.803 & 1.788 \\
\hline & C & 2.229 & 2.201 & 2.194 & 2.150 & 2.139 & 2.101 & 2.086 \\
\hline
\end{tabular}
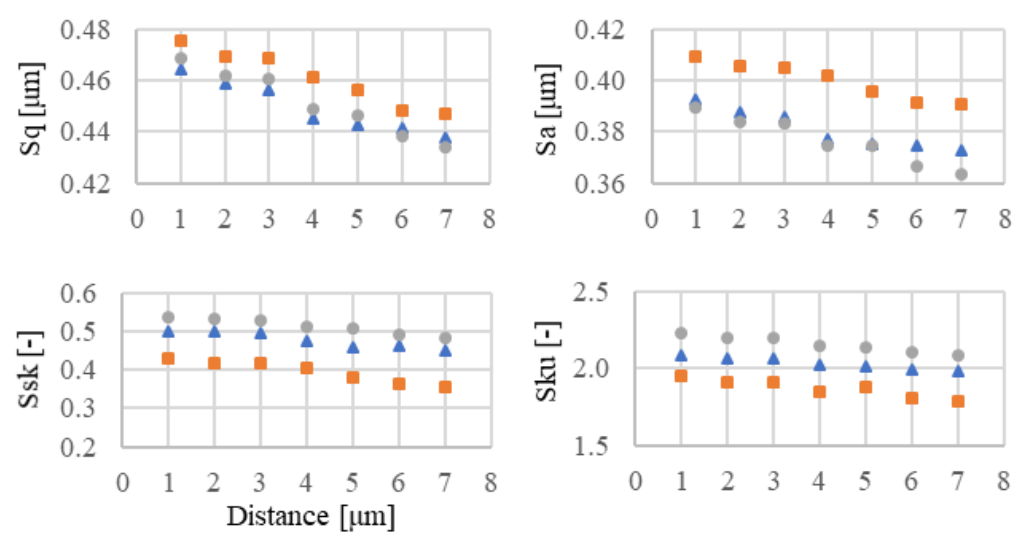

$\Delta$ Area $=$ Area B * Area C

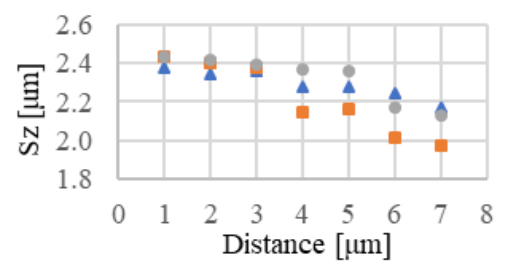

Figure 4 - Roughness values as a function of $\mathrm{X}$-direction point density

\section{CONCLUSIONS}

The roughness of a topography is a topic increasingly often being studied in industry and in different research areas; however, areal roughness is examined differently in terms of measurement settings and method of evaluation. In the present paper, the effect of three roughness measurement setting parameters on the areal roughness was investigated on a face milled specimen, measured with a confocal chromatic sensor. During the analysis I drew the following conclusions.

Changing the measurement speed in the main direction resulted in small differences in the roughness values in the area aligned to the plane of symmetry, and there was a 4.5\% maximum deviance of the values. With the increase of the velocity, there was a random change in $S_{\mathrm{a}}, S_{\mathrm{q}}$ values, and a decrease in $S_{\mathrm{z}}, S_{\mathrm{sk}}$, and $S_{\mathrm{ku}}$. I found the smallest differences within the studied range at higher speed values. The measurement was performed in a speed range where the measurements read from the detector were equal 
or less than the value of the sensor sampling frequency during the measurements, so the observations are valid only in this range.

The distances of the points taken along the main direction were examined at three different locations on the surface: in the plane of symmetry of the workpiece and at equal distances in two directions from it. There was a slight decrease in roughness values with increasing distance. The skewness and kurtosis values hardly changed, the parameters $S_{z}, S_{a}, S_{q}$ showed the least change at the smaller values of the examined range $(1-3 \mu \mathrm{m})$.

Analyzing the distance of the points taken perpendicular to the main direction, the variance of the values in each measurement area was small, but it was random/scattered. Overall, minimal deviations were measured per area in the middle part of the studied range $(5-15 \mu \mathrm{m})$.

Ranking the examined areal roughness parameters in ascending order according to their overall sensitivity to the changed setting parameters, the smallest differences were found in $S_{\mathrm{ku}}$ kurtosis and $\mathrm{S}_{\mathrm{sk}}$ skewness. These are followed by the $\mathrm{S}_{\mathrm{q}}$ root-mean-square average, which had a smaller deviation than the $S_{a}$ average roughness. The greatest variability was given by the values of $S_{z}$ total height.

\section{ACKNOWLEDGEMENT}

The described study was carried out as part of the EFOP-3.6.1-16-00011 "Younger and Renewing University - Innovative Knowledge City - institutional development of the University of Miskolc aiming at intelligent specialization" project implemented in the framework of the program Szechenyi 2020.

References: 1. I. Zagórski, J. Korpysa: Surface Quality Assessment after Milling AZ91D Magnesium Alloy Using PCD Tool, Materials vol.13(3) (2020) ArtNo:617. 2. B. Karpuschewski, J. Kundrák, T. Emmer, D. Borysenko: A New Strategy in Face Milling - Inverse Cutting Technology, Solid State Phenomena vol.261 (2017) pp.331-338. 3. J. Kundrak, C. Felho: 3D roughness parameters of surfaces face milled by special tools, Manufacturing technology vol.16(3) (2016) pp.532-538. 4. G. Varga, J. Kundrák: Effects of Technological Parameters on Surface Characteristics in Face Milling, Solid State Phenomena vol.261 (2017) pp.285-292. 5. Jiang, X., Scott, P. J., Whitehouse, D. J., Blunt, L.: Paradigm shifts in surface metrology. Part I. Historical philosophy, Proceedings of the Royal Society A: Mathematical, Physical and Engineering Sciences vol.463(2085), (2007) pp.2049-2070. 6. S.K. Fecske, K. Gkagkas, C. Gachot, A. Vernes: Interdependence of Amplitude Roughness Parameters on Rough Gaussian Surfaces, Tribology Letters vol.68(1) (2020) pp.1-15. 7. K. Klauer, M. Eifler, B. Kirsch, J. Seewig, J.C. Aurich: Ball end micro milling of areal material measures: influence of the tilt angle on the resulting surface topography, Production Engineering vol.14(2) (2020) pp.239-252. 8. M. Niemczewska-Wójcik, A. Wójcik: The multiscale analysis of ceramic surface topography created in abrasive machining process, Measurement vol.166 (2020) ArtNo:108217. 9. S. Wojciechowski, R. Talar, P. Zawadzki, S. Legutko, R. Maruda, C. Prakash: Study on Technological Effects of a Precise Grooving of AlSi1 ${ }_{3} \mathrm{MgCuNi}$ Alloy with a Novel WCCo/PCD 
(DDCC) Inserts, Materials vol.13(11) (2020) ArtNo:2467. 10. K Mouralova, L Benes, T Prokes, J Bednar, R. Zahradnicek, J. Fries: Machining of pure molybdenum using WEDM, Measurement vol.163 (2020) ArtNo:108010. 11. Geometrical product specifications (GPS) - Surface texture: Areal — Part 3: Specification operators. ISO 25178-3:2012. Geneva: International Organization for Standardization.

Антал Надь, Мішкольц, Угорщина

\title{
ВПЛИВ НАЛАШТУВАНЬ КОНФОКАЛЬНОГО ХРОМАТИЧНОГО ДАТЧИКА НА РЕЗУЛЬТАТИ ВИМІРЮВАНЬ ШОРСТКОСТІ ФРЕЗЕРОВАНОЇ ПОВЕРХНI
}

\begin{abstract}
Анотація. Вимірювання шорсткості має особливо важливе значення у виробництві для опису контролю якості виробничих прочесів щодо функиіональних, трибологічних $i$ інших властивостей поверхонь деталей. Поверхнева шорсткість, яка вивчалася на топографії, стала більш поширеною, оскільки вона забезпечує більш точний $і$ докладний опис поверхонь. Для вимірювань зразків використовувався прилад для тривимірного вивчення шорсткості AltiSurf 520. Вимірювалася поверхня конфокальним хроматичним датчиком CL2 з лупою MG140, ияо має вертикальний діапазон виміру 300 мкм і чутливість 0,012 мкм. Частота дискретизації датчика становила 1000 Ги. Розмір вимірюваних областей був обраний 1,25 × 1,25 мм², виходячи 3 рекомендаиії ISO 25178-3:2012. Налаштування процесу вимірювання повторювалися тричі, і їх середньоарифметичні значення були використані для досліджень. Очінка вимірювань виконувалася в програмі AltiMap Preтіuт v6.2. У кожному разі застосовувалися різні фільтри на $S$-L-поверхняx, спочатку усуваючи дефект форми, що означало вирівнювання на плоскій поверхні, потім за допомогою функиї «Поріг» вирізалися дефектні частини на топографії $i$, нарешті, встановлювався фільтр Гауса, а разом з ним $і$ L-фільтр $(\lambda c=0,25$ мм). Зміна швидкості вимірювання в основному напрямку привела до невеликих розбіжностей в значеннях шорсткості в області, суміщеної з площиною симетрії, і максимальне відхилення значень склало 4,5\%. $3 і$ збільшенням швидкості відбувалася випадкова зміна значень $S_{a}, S_{q} i$ зменшення $S_{z}, S_{s k} i S_{k u}$. Найменші відмінності в досліджуваному діапазоні були виявлені при більш високих значеннях швидкості. Вимірювання проводилося в діапазоні швидкостей, в якому вимірювання, зняті $з$ детектора, були рівні або менше значення частоти дискретизаиії сенсора, тому спостереження дійсні тільки в иььму діапазоні.
\end{abstract}

Ключові слова: шорсткість поверхні; зональна шорсткість; конфокальний хроматичний датчик. 